\title{
In Situ Nanoscale Observations of Metatorbernite Surfaces Interacted with Aqueous Solutions
}

\author{
José Manuel Astilleros, ${ }^{*,+\ddagger}$ André Jorge Pinto, ${ }^{\S}$ Mário A. Gonçalves, ${ }^{\S}$ Nuria \\ Sánchez-Pastor, ${ }^{\dagger}$ and Lurdes Fernández-Díaz ${ }^{\dagger, f}$ \\ †Departamento de Cristalografía y Mineralogía, Universidad Complutense de Madrid, C/José Antonio Novais 2, Madrid 28040, Spain

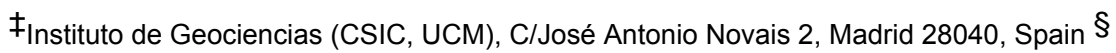 \\ Department of Geology and CREMINER/LARSys, Faculty of Sciences, University of Lisbon, Ed. C6, 1749-016 Lisbon, Portugal
}

\begin{abstract}
Metatorbernite $\left(\mathrm{Cu}\left(\mathrm{UO}_{2}\right)_{2}\left(\mathrm{PO}_{4}\right)_{2} \cdot 8 \mathrm{H}_{2} \mathrm{O}\right)$ has been identified in contaminated sediments as a phase controlling the fate of $\mathrm{U}$. Here, we applied atomic force microscopy (AFM) to observe in situ the interaction between metatorbernite cleavage surfaces and flowing aqueous solutions (residence time $=1 \mathrm{~min}$ ) with different $\mathrm{pHs}$. In contact with deionized water the features of $(001)$ surfaces barely modify. However, changes are remarkable both under acidic and basic conditions. In acidic solutions $(\mathrm{pH}=2.5)$ metatorbernite surface develops a rough altered layer and large pits nucleate on it. The altered layer shows a low adhesion and is removed by the AFM tip during the

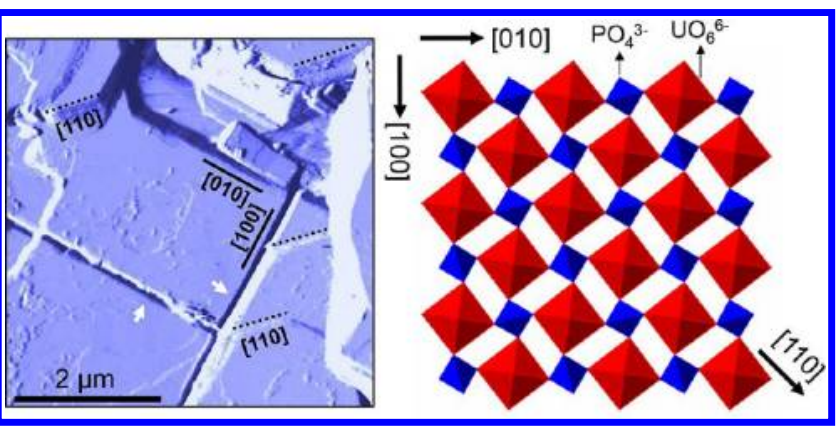
scanning. The large pits spread rapidly,

at few tens of $\mathrm{nm} / \mathrm{s}$, indicating a collapse of the structure. The combination of dissolution and the presence of defects in the metatorbernite structure can explain both the collapse process and the alteration of the surfaces under acidic conditions. Other mechanisms such as ion exchange reactions remain speculative. In $\mathrm{NaOH}$ solutions $(\mathrm{pH}=11.5)$ metatorbernite dissolves by formation of etch pits bounded by steps parallel to $\langle 100\rangle$, the direction of the most straight periodic bond chains (PBCs) in metatorbernite structure. These steps retreat at $\sim 0.15 \mathrm{~nm} / \mathrm{s}$. Under these conditions dissolution is promoted by the formation of stable uranyl carbonate complexes in solution.
\end{abstract}

\section{INTRODUCTION}

Uranium minerals have been the subject of great attention due to their importance as an energy resource since they are the greatest known stock of nonrenewable energy on Earth ${ }^{1}$ Under subsurface and reducing conditions uraninite $\left(\mathrm{UO}_{2}\right)$, which is by far the most important uranium mineral in terms of abundance and economic value. 2 However, during mining and processing of uranium ores, large amounts of radioactive wastes are produced and frequently exposed to the oxidizing conditions of the atmosphere and hydrosphere
uranium can be easily mobilized in the form of the mobitions, uranyl ion (UO $\mathrm{U}_{2}^{2+}$, providing a rich source of this element groundwaters 3,4 Therefore, the development of efficient gromediation strategies for contaminated sites is an urgent task. One of the most common technical solutions is based on the surface reactivity of inorganic materials. A notable example is the efficiency experimentally shown by apatite $\left(\mathrm{Ca}_{5}\left(\mathrm{PO}_{4}\right)_{3}(\mathrm{OH}, \mathrm{F})\right)$, which is able to induce an effective removal of uranium from solution ${ }^{5}$ lowering its concentration nearly to proposed drinking water standards. 6 and, more effectively, by precipitation of uranyl phosphates minerals of the autunite and meta-autunite groups. 5,7
In the latter caseapatite dissolves, providing a low but sufficient concentration of $\mathrm{PO}_{4}{ }^{3-}$ in solution. As a result, the solubility of certain uranyl minerals is exceeded, leading to their rapid precipitation.

On the other hand, since phosphate ion is a ubiquitous constituent of many natural waters, the formation of such minerals naturally controls uranium concentrations in the environment. ${ }^{2}$ For instance, Jerden et al ${ }^{8}$ showed that the precipitation of meta-autunite group minerals in a soil developed over a uranium deposit can reduce the dissolved uranium concentrations to values lower than the USEPA maximum contaminant level. Of all meta-autunite minerals, metatorbernite arises as one of the most environmentally relevant phases. Metatorbernite has been found to be the mineral controlling the macroscopic release of uranium in contaminated sediments, for instance in locations such as the Hanford site in Washington, where plutonium for nuclear weapons was produced during World War II and the Cold War-ipitation of metatorbernite and other meta-autunite minerals is of prime geochemical importance because they 


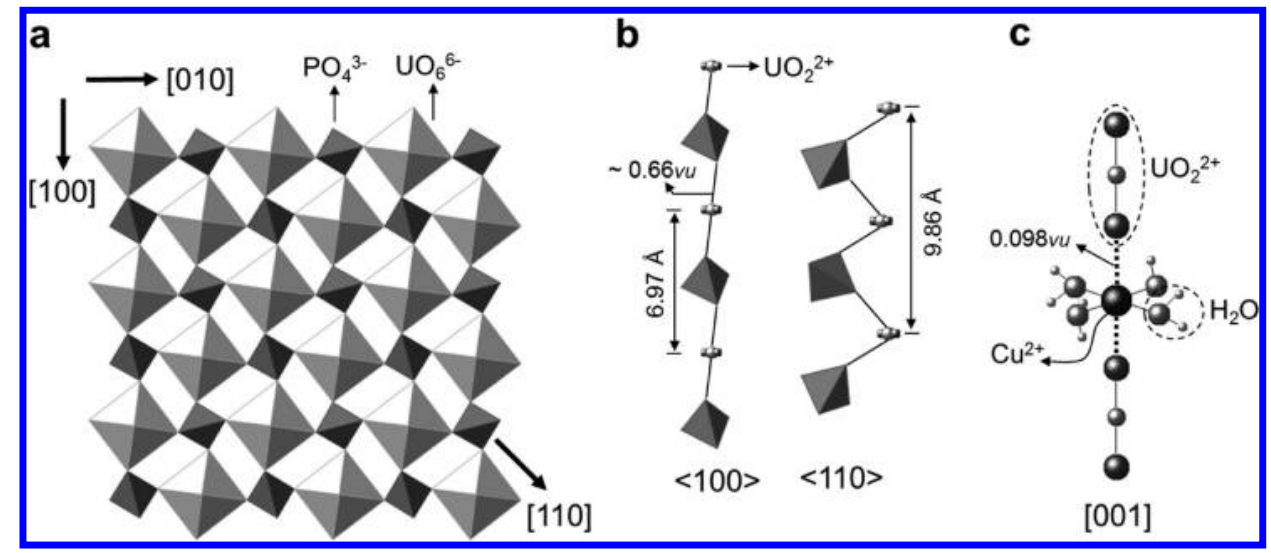

Figure 1. (a) Polyhedral representation of the uranyl phosphate sheet in metatorbernite according to Locock and Burns, 21 viewed along [001]. It consists of corner-shared tetrahedra of $\mathrm{PO}_{4}{ }^{3-}$ (dark gray) and square bipyramids of $\mathrm{UO}_{6}{ }^{6-}$ (light gray). (b) PBCs running along $\langle 100\rangle$ and $\langle 110\rangle$. Strong bonds connect $U$ with closer $\mathrm{O}$ of the phosphate tetrahedra. (c) Cu $2+$ ion is order to get a better visualization of the uranyl ion (b) and the water molecules (c). The Cu atom is not to scale. Explanatory note: the standard crystallographic notation system was used throughout the text to denote planes, forms, directions, and set of equivalent directions: (hkl) and $\{\mathrm{hkl}\}$ symbols refer to a single plane or face and a crystallographic form, respectively, whereas [uvw] and $\langle u w v\rangle$ symbols denote a single lattice direction and a set of symmetrically equivalent directions, respectively.

are common secondary phases in most weathered

uranium primary deposits. $2,13,14$

It is evident that uranyl phosphates can subsequently alter as they continue to interact with groundwaters (i.e., by weath-ering). For this reason, in recent years several macroscopic studies concerning the dissolution kinetics of minerals of the autunite and meta-autunite groups have been carried out. ${ }^{15-17}$ Such studies evaluated the effects on the dissolution kinetics of different parameters such as temperature, $\mathrm{pH}$, organic and inorganic compounds, redox conditions, and the bacterial activity. However, as far as we know, the present study is the first to directly apply atomic force microscopy to investigate processes occurring at the nanoscale during the interaction of mineral surface-aqueous solutions in such systems. Previous studies $18-20$ reporteg other nonphosphate uranyl minerals such as oxyhydroxides, silicates, and sulphates, although most of these studies were conducted under nonflow ex situ conditions. In this work, we use an atomic force microscope (AFM) to study, for the first time, crystals of the meta-autunite group. More

specifically, metatorbernite $\left(\mathrm{Cu}\left(\mathrm{UO}_{2}\right)_{2}\left(\mathrm{PO}_{4}\right)_{2} \cdot 8 \mathrm{H}_{2} \mathrm{O}\right)$ (001) surfaces were interacted with aqueous solutions under circum-neutral conditions and rather acidic $(\mathrm{pH}=2.5)$ and alkaline conditions $(\mathrm{pH}=11.5)$. We focus on the (001) surface because it corresponds to the most important face in most habits of natural metatorbernite. This mineral displays structural and physicochemical properties similar to the rest of the meta-autunite minerals, including a perfect (001) basal

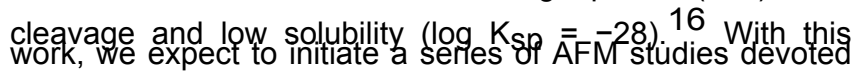
to gaining a better understanding of the reactivity of autunite and meta-autunite minerals at nanoscale and under different conditions. These are crucial assessments to expand the current knowledge of the factors controlling $\mathrm{U}(\mathrm{VI})$ mobility in the environment, especially concerning the fate of secondary uranyl-phosphates derived from primary ore mineralizing events.

\section{MATERIALS AND METHODS}

In situ AFM experiments were carried out to study the changes in the microtopography and the dissolution kinetics occurring on metatorbernite (001) surfaces when they interacted with aqueous solutions. For this purpose, natural metatorbernite samples from the Musonoi Mine, Kolwezi, Katanga (Shaba) Province, Democratic Republic of Congo were purchased from the Mineralogical Research Company, San Jose, CA. Meta-torbernite crystals were millimeter sized and exhibited emerald-green color and tabular habit. The crystals were studied by standard scanning electron microscopy (SEM) (JEOL JSM 6400, $40 \mathrm{kV}$ ). SEM imaging of the crystals provided information about textural and mineralogical features. Energy-dispersive X-ray spectroscopy (EDX) analyses carried out on selected areas of the crystals showed that they are mainly composed of $\mathrm{U}, \mathrm{P}$, and $\mathrm{Cu}$. Both the composition and the habit of these crystals are consistent with those of metatorbernite, which was also confirmed by powder XRD of crushed material using a Philips X'Pert-MPD equipped with a Cu Ka (1.5405 A) X-ray source.

Experiments were conducted in situ in a fluid cell of an AFM (Digital Instruments, Nanoscope Illa, Multimode) at room temperature. All the AFM images shown in this work were taken in constant force mode while displaying both cantilever height and deflection signals. The scan time for each image was approximately $1 \mathrm{~min}$ with a scan rate of 5.2 $\mathrm{Hz}$. Silicon nitride tips (Veeco NP-S10) with a nominal force constant $\mathrm{k}=0.06-0.58 \mathrm{~N} / \mathrm{m}$ were used. Freshly cleaved metatorbernite surfaces were used as a substrate. However, the preparation of metatorbernite for AFM experiments presents difficulties that other materials with perfect cleavage, such as calcite and gypsum, do not impose. Metatorbernite crystals were extremely brittle and easily shattered after contact with the cleaving blade. As a consequence, obtaining good-quality cleaved surfaces was a tricky task. Several attempts were commonly required to obtain a suitable cleaved surface fragment, which involved a considerable loss of material. Once a large enough fragment (1-2 $\mathrm{mm}$ ) was obtained, it was carefully placed in the fluid cell $(50 \mu \mathrm{L}$ volume). This gave a ratio solid/liquid of $\sim 0.14$ $\mathrm{mL} / \mathrm{g}$, since the estimated mass of the metatorbernite fragments was

$\sim 7.0 \mathrm{mg}$. Before each dissolution experiment, deionized water (18.2 M $2 . \mathrm{cm}$, Milli-Q) was passed over the crystal to clean the cleaved (001) metatorbernite surface and adjust the AFM parameters. Aqueous solutions were prepared immediately prior to the start of each experiment. Target $\mathrm{pHs}$ of 2.5 and 
11.5 were obtained by adding hydrochloric acid and sodium hydroxide to the deionized water. Afterward, the fluid cell was filled with an aqueous solution. To avoid solution/ sample equilibrium a flow of solution was maintained by injecting fresh solution at intervals of about $1 \mathrm{~min}$ between each AFM scan. Measurements on recorded sequences of recorded AFM images allowed us to quantify the nanotopographic changes occurring during the dissolution process.

Additionally, in the experiments conducted at $\mathrm{pH} 2.5$ the effluent solutions were collected and analyzed for $\mathrm{U}, \mathrm{Cu}$, and $\mathrm{P}$ using inductively coupled plasma-optical emission spectrom-etry (ICP-OES) (SPECTRO ARCOS).

\section{STRUCTURE, HABIT, AND SURFACE FEATURES OF METATORBERNITE CRYSTALS}

Since mineral-aqueous solution interaction takes place mainly at the interface, a comprehensive study of interaction processes requires the knowledge of the crystal structure and surface features of the crystals used in the experiments.

Metatorbernite crystallizes in the tetragonal spatial group the a with a $=6.976 \AA \AA$ and $c=17.349 \AA \AA^{2} 21$ it is a member of briefly described as consisting of parallel sheets of

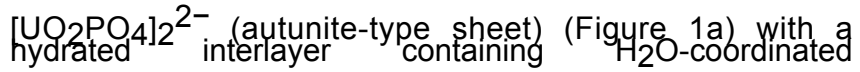
cations 22,23 In the case of metatorbernite, the former
sheet is undistorted and contains two clear periodic bond chains (PBCs) running within the sheet: $\langle 100\rangle$ and $\langle 110\rangle$ (Figure 1b; for an explanation of the crystallographic symbols used in text see the explanatory note in the figure caption). Both consist of direct chains of U-O-P-O-U links with identical $\mathrm{U}-\mathrm{O}$ bond length $(\sim 2.30 \AA)$ and bond strength bonding ve network along ${ }^{24}$ Whereas $\langle 100\rangle$ forms a zigzaite chain with the longer repeating period $(9.86 \AA)$ than that of the PBCs along $\langle 100\rangle(6.97 \AA)$. The strong bonding networks within the sheets clearly points toward the pinacoid $\{001\}$ as the dominating form in metatorbernite, which is in agreement with the habit observed in our samples (Figure 2) and in most natural samples. 25 This flat form is frequently combined with rougher hol
in the interlayer between the uranyl phosphate sheets and are octahedrally coordinated by four equatorial $\mathrm{H}_{2} \mathrm{O}$ groups and two axial $\mathrm{O}$ of the uranyl (OUr) ions from each adjacent sheet (Figure 1c). It forms a distorted $(4+2)$ octahedron owing to the Jahn-Teller effect which yields a large $\mathrm{Cu}-\mathrm{O} U \mathrm{r}$ distance and weak bond strength ( 0.098 v.u.). The interlayer also contains an $\mathrm{H}_{2} \mathrm{O}$ group that is held in the structure by $\mathrm{H}$ bonds only. The weak nature of both the $\mathrm{H}$ and the Cu-OUr bonds easily explains the perfect (001) mica-like basal cleavage and its remarkable ion exchange capacity. This property can be enhanced by the presence of defects in the crystal structure and cracks throughout the crystal which enable a rapid and more effective contact between the hydrated interlayer and the interacting aqueous solutions.

\section{RESULTS AND DISCUSSION}

Freshly cleaved metatorbernite (001) faces observed by AFM frequently show atomically rough surfaces with multilayer straight steps running along different directions (Figure $3 a-c)$. Most of steps observed are parallel to $\langle 100\rangle$ although rougher steps running parallel to $\langle 110\rangle$ and other undefined crystallo-graphic directions are also found. Orientation of straight $\langle 100\rangle$

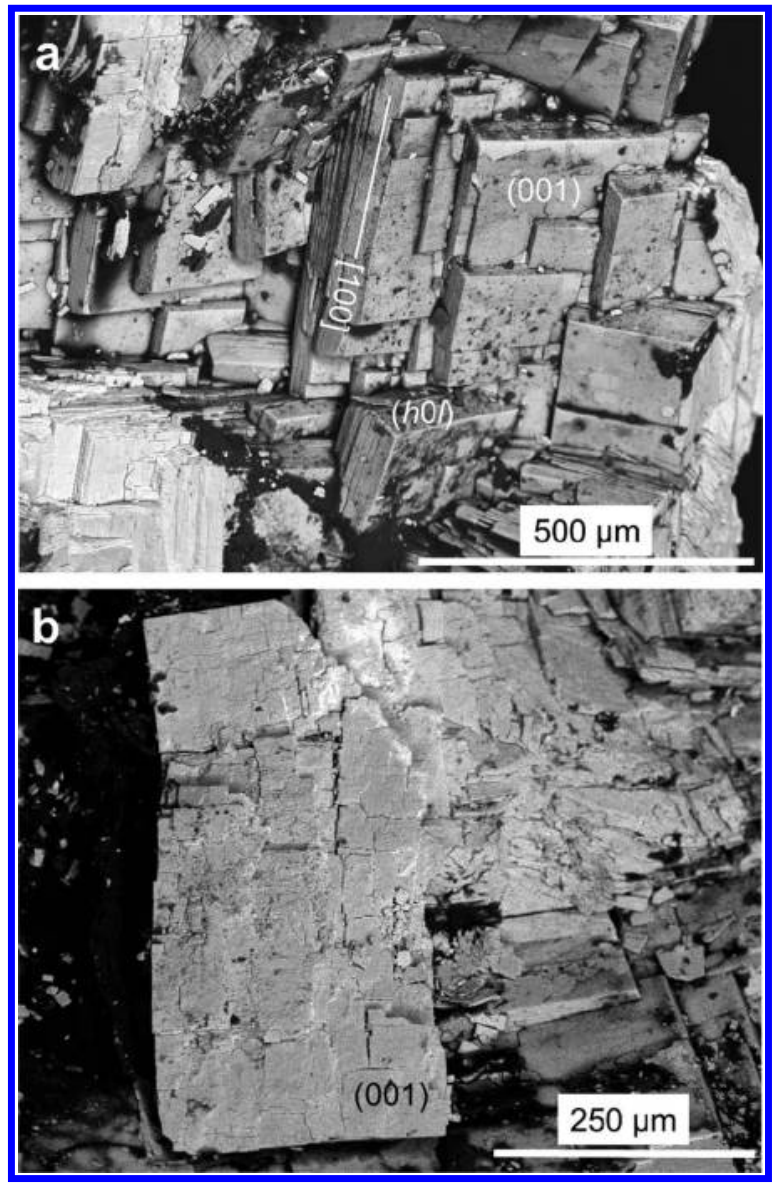

Figure 2. (a) SEM images of an aggregate of tabular metatorbernite crystals as used in the experiments. The habit of most crystals is a combination of the $\{001\}$ pinacoid with $\{\mathrm{hOl}\}$ tetragonal bipyramids (most probably $\{101\}$ ) or $\{100\}$ tetragonal prisms. Basal cleavage is clear in most of the crystals. (b) Detail of (001) face of metatorbernite crystal. It surface exhibits a profuse number of cracks roughly running along $\langle 100\rangle$ directions.

and rougher $\langle 110\rangle$ steps are mainly controlled by the distribution of PBCs within the $\left[\mathrm{UO}_{2} \mathrm{PO}_{4}\right]_{2}^{2-}$ sheet described in the previous section. Both the different height and orientation of the multilayer steps can result in very complex microtopography. Indeed, it is frequent to find the presence of isolated flat-topped islands protruding from the main cleaved surface (Figure $3 a-b$ ). In addition, the surface is frequently segmented, forming a micromosaic-like structure (Figures $3 c-d$ ). Each individual block forming the mosaic is separated from surrounding blocks by cracks of variable width and depth running across the surface. Moreover, blocks can be slightly tilted relative to each other. Cracks across $\{001\}$ surfaces are also evident in some SEM images (see Figure $2 b$ ). The mosaic-like structure is typical of very defective crystals and is the result of the development of a dislocation network 26 Moreover, this is also probably responsible for the brittle behavior' of the metatorbernite crystals. AFM images also reveal atomically flat terraces and half-monolayer steps running along $\langle 100\rangle$, $\langle 110\rangle$, and other less relevant crystallographic directions.

3.1. Dissolution under Deionized Water. Metatorbernite (001) surfaces in contact with deionized water do not undergo changes in surface morphology to an extent that can be observable by AFM. Neither dissolution processes (by nucleation of etch pits on the flat terraces and/or step retreat) 


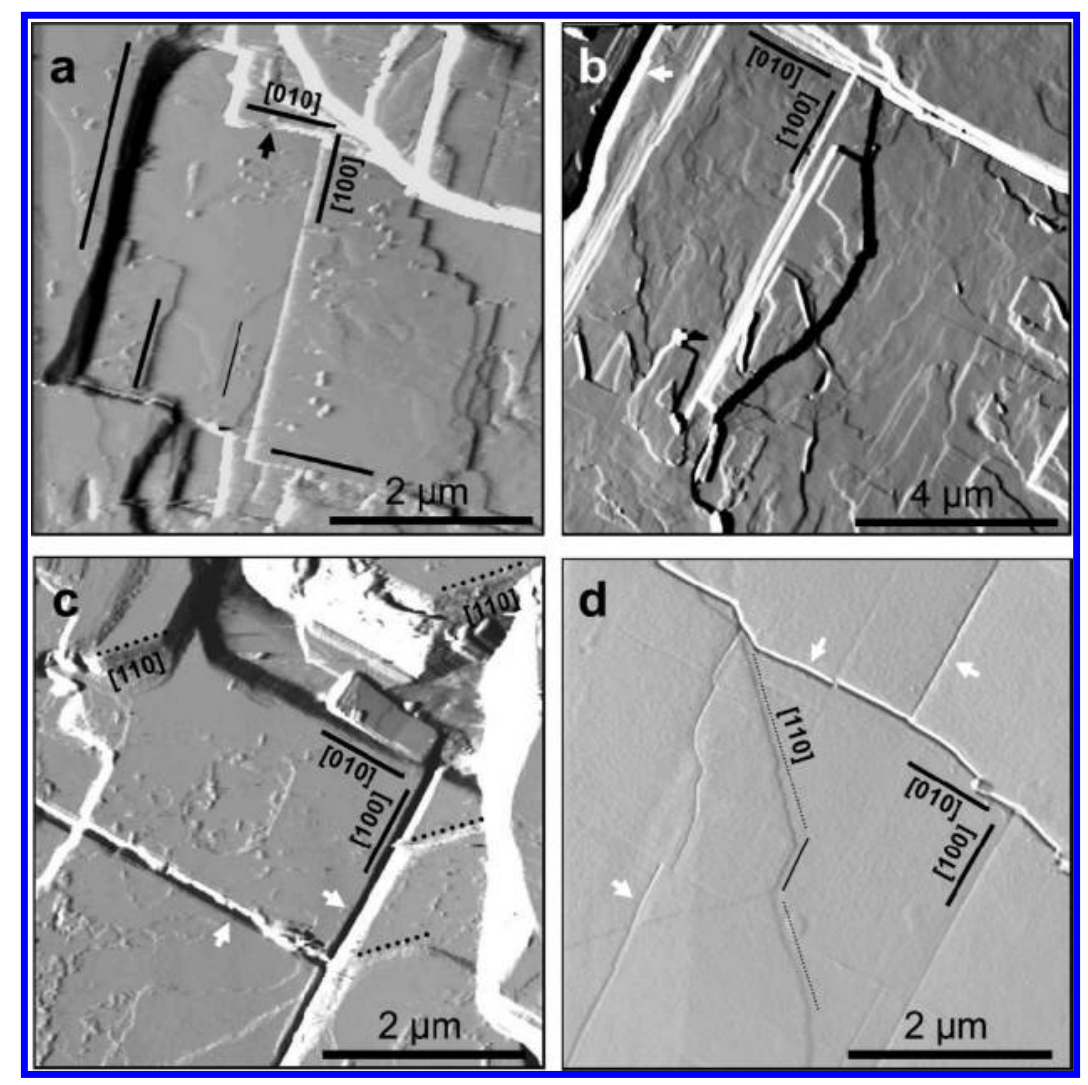

Figure 3. AFM images (deflection images) of cleaved (001) surfaces of metatorbernite in water. Surfaces are frequently rough with both multilayer (thick lines) and monolayer (thin lines) steps running along $\langle 100\rangle$ (solid lines), $\langle 110\rangle$ (dashed lines) and other less relevant crystallographic directions. The surfaces frequently show isolated flat-topped islands bounded by multilayer steps $(a-b)$. Crystals often develop micromosaic-like structure (c-d), with tabular blocks separated each other by cracks of variable width and depth running across the surface (with arrows). AFM images showing large areas of flat terraces (d) are scarce.

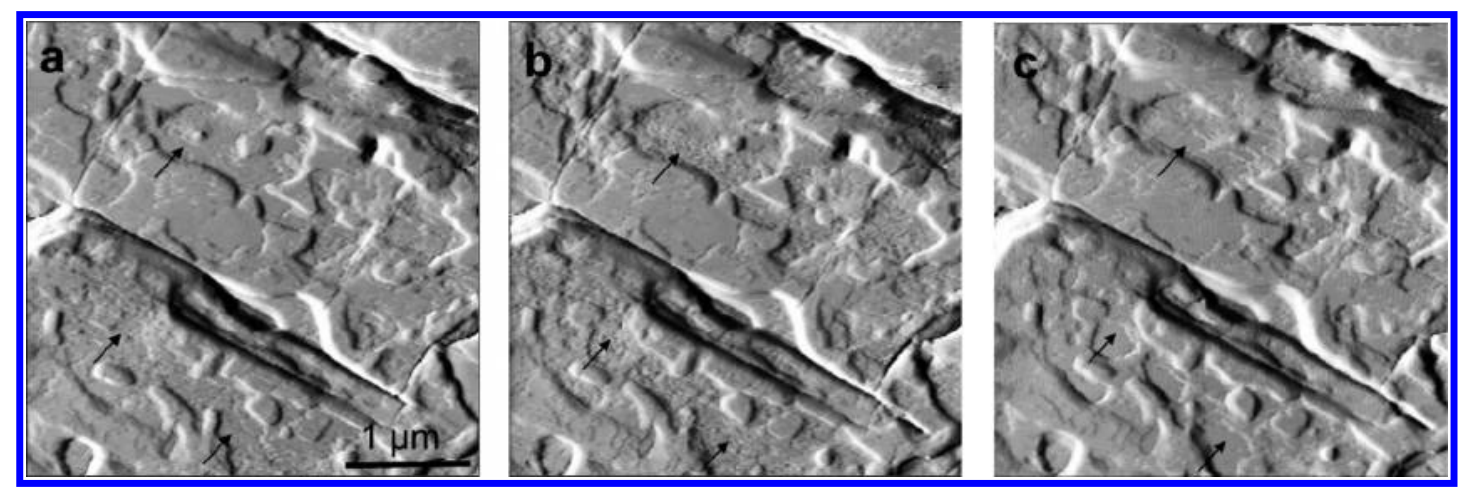

Figure 4. Sequence of images of metatorbernite at $\mathrm{pH}=2.5$ showing roughening of certain areas of the surfaces (black arrows). After several minutes of interaction the rough surface becomes flat again. Time elapsed between successive images is around $6 \mathrm{~min}$.

nor alteration of the substrate were observed even after large periods of interaction ( $>30 \mathrm{~min})$. This behavior is consistent with the extremely low solubility of metatorbernite. 16,27-29

3.2. Dissolution under $\mathrm{pH} 2.5$ Solution. The exposure of the metatorbernite surface to acidic and basic solutions leads to a significant and rapid modification of its surface micro-topography.

Figure 4 shows a representative AFM sequence of dissolution of a metatorbernite (001) surface interacting with an acidic solution $(\mathrm{pH}=2.5)$. Under such conditions, the surface layer appears significantly altered when compared to the starting surface. The evidence for the occurrence of an altered surface arises from several observations. First, it is recognizable by the

rapid change in the surface roughness, i.e., the initially flat surface clearly roughened significantly (Figure $4 a-b)$. Moreover, this process seems to reverse since after several minutes of interaction the rough surface becomes flat again (Figure 4c). Such behavior can be explained if we assume the removal of an altered layer by the application of frictional forces with the AFM tips during the scanning. The surface not only becomes rough, but also soft as a consequence of the alteration process. The removal of this soft layer reveals a pristine interface underneath which becomes rough again once it gets into contact with the acidic solution. This alternation of rough-flat surfaces is coherent with a sheetlike structure controlling the dissolution process. Figure 5 shows a created scan field, i.e., the 


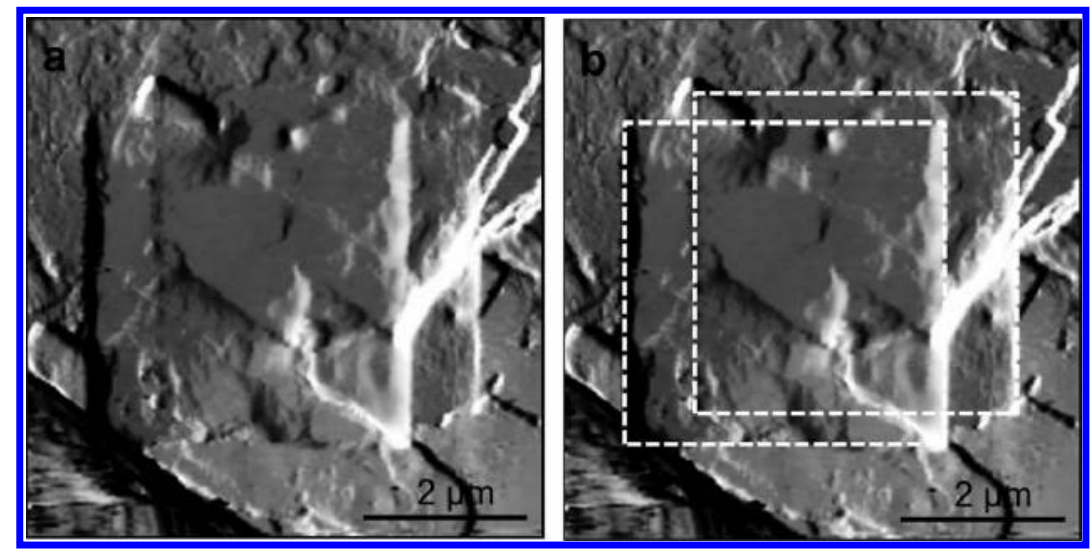

Figure 5. (a) AFM image showing two superimposed scan fields $(4 \mu \mathrm{m})$ on metatorbernite (001) at pH of 2.5. The scans were created a few minutes before the image was taken. Note the altered surface surrounding the flatter scan fields. (b) Dotted lines indicate the precise limits of the scan fields.

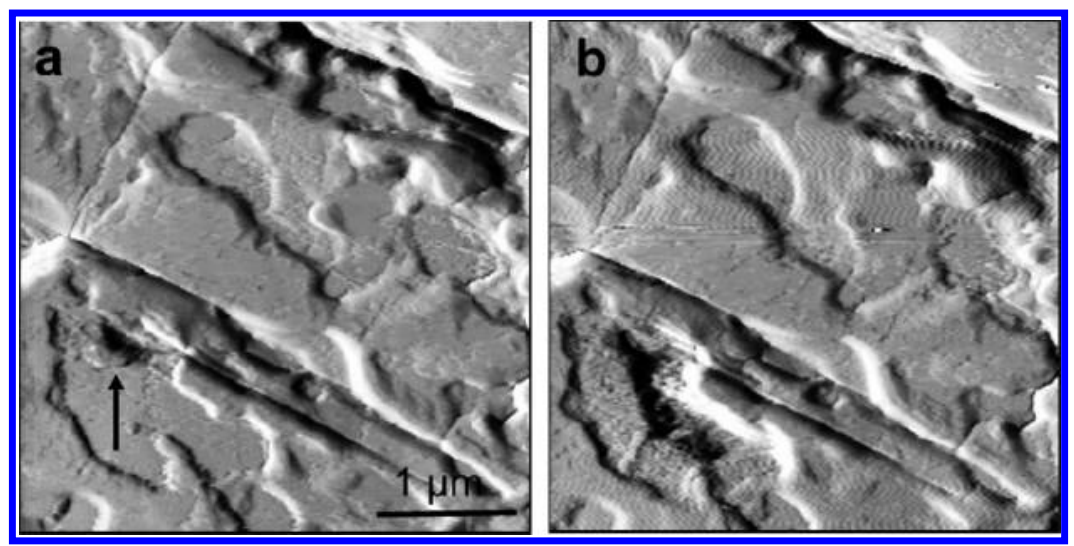

Figure 6. AFM images of metatorbernite at $\mathrm{pH}=2.5$ showing the formation of a large pit (see black arrow) (a) which rapidly spreads, increasing both its lateral and vertical size (b). The pit bottom (depth: a few micrometers) shows a rough surface oriented parallel to (001). The pit nucleation takes place along a crack allowing the aqueous solution an easy access to the crystal bulk. Time elapsed between successive images is around $2 \mathrm{~min}$.

retreat of the interface in the scan field area, due to the removal of the soft surface layer by the scanning tips. A similar behavior has been previously observed using a hydrothermal atomic force microscope (HAFM) during the acidic $(\mathrm{pH}=2)$ dissolution of plagioclase at temperatures up to $125^{\circ} \mathrm{C}$. 30 These authors unequivocally equate the soft layer with an altered layer resulting from exposure to acidic solution. It is worth noting that the roughening at the surfaces is not uniform: whereas some areas remain relatively unaltered others undergo significant alteration. This behavior may have a variety of possible interpretations including local changes in composition or unequal distribution of structural defects. Finally, after several minutes of interaction, in some areas of the interacted surface we observed (see Figure 6) the nucleation of a very large pit bounded by rough walls emerging from the lower left side of the image. The pit bottom (depth: a few micrometers) showed a rough surface that was oriented parallel to (001). The pit rapidly spreads increasing both its lateral and vertical size. Measurements of the lateral spreading rate of the pit indicate a speed in the order of a few $\mu \mathrm{m} / \mathrm{min}$ and points toward the collapse of the metatorbernite structure in such area. Although structural heterogeneities can be responsible for the collapse process, it cannot be excluded that a chemical reaction process is taking place underneath the metatorbernite surface. Such process would be enhanced by the presence of cracks throughout the crystal, which allowed the aqueous solution to gain rapid access to the crystal bulk. Indeed, Figure 6 shows how the pit nucleation takes place along a crack.

A possible mechanism explaining these processes involves a partial substitution of $\mathrm{Cu}$ by $\mathrm{H}_{3} \mathrm{O}$, due to a ion exchange reaction according to the following:

$$
\begin{aligned}
& \mathrm{Cu}\left(\mathrm{UO}_{2}\right)_{2}\left(\mathrm{PO}_{4} \text { 帐 } \mathrm{Q}+\mathrm{H}_{3}^{+}\right. \\
& \leftrightarrow\left(\mathrm{Cu}_{1 / 2} \mathrm{H}_{3}\right)\left(\mathrm{UO}_{2}\right)_{2}\left(\mathrm{PO}_{4}\right)_{2} \cdot n \mathrm{H}_{2} \mathrm{O}+1 / 2 \mathrm{Cu}^{2+}
\end{aligned}
$$

These ion exchange-assisted reactions are known to occur in layered minerals of the meta-autunite group as an intermediate step toward their mineral transformation. ${ }^{14} \mathrm{In}$ metatorbernite it can take place between the $\left[\mathrm{UO}_{2} \mathrm{PO}_{4}\right]_{2}{ }^{2-}$ negatively charged layers, where the $\mathrm{Cu}^{2+}$ is located, and negatively charged layers, where the $\mathrm{Cu}^{2+}$ is located, and
results from bond breaking and weakening along the interlayer. Moreover, the reaction entails a decrease in molar volume due to the large differences between the molar volumes of metatorbernite 21 and chernikovite. 31 Since replacement reactions do not usually cause a change in crystal morphology and volume, the formation of porosity must necessarily occur. $32-34$ such porosity should be must necessarily occur between the layers (interlayer porosity), shince pure exchange reactions of $\mathrm{Cu}^{2+}$ for $\mathrm{H}_{3} \mathrm{O}^{+}$leave, in principle, the forces to $\mathrm{UO}_{4} \mathrm{P}_{2}^{2-}$ sheets unaltered. The application of loading collapse of the upper sheets. Another alternative mechanism for the creation of porosity would involve a coupled 


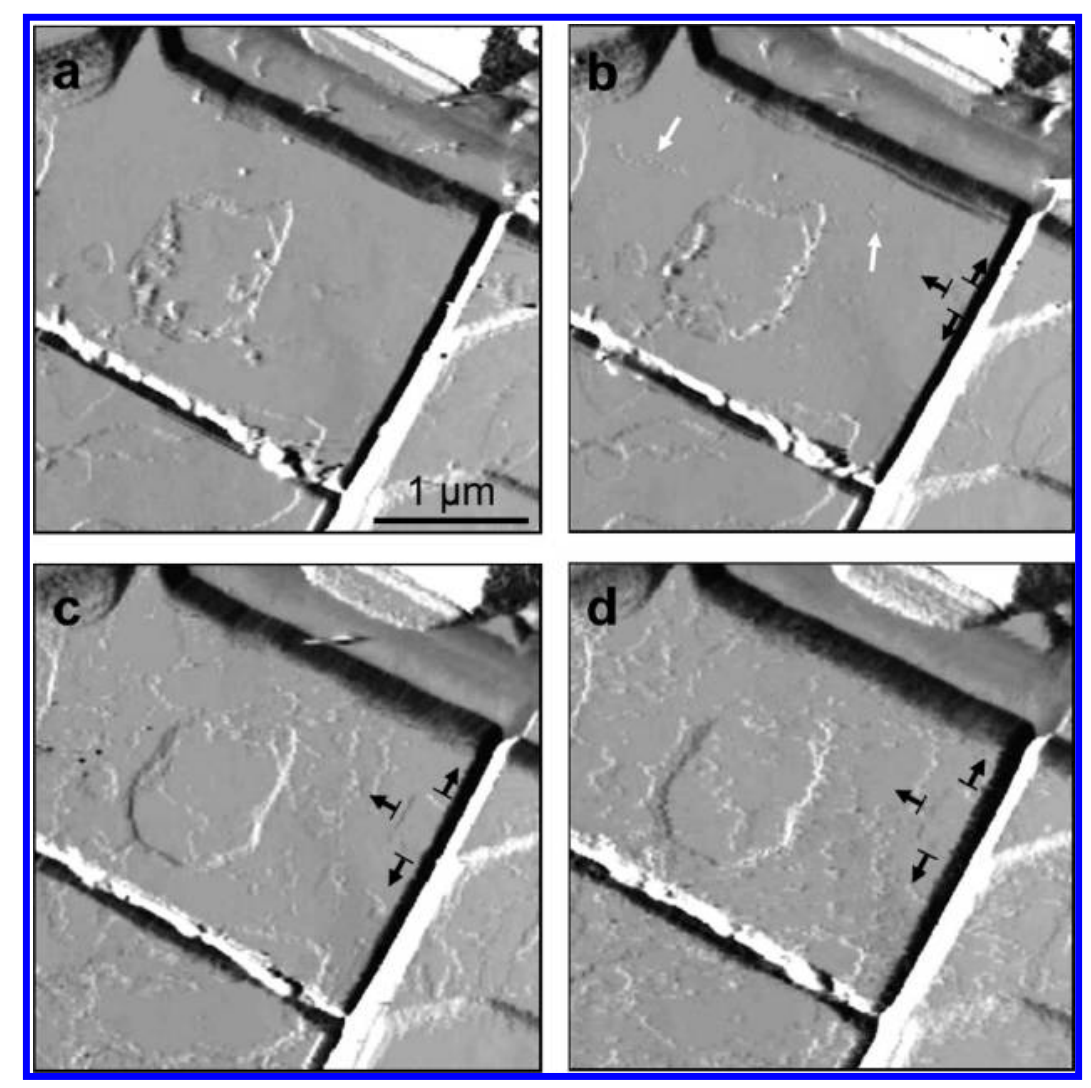

Figure 7. AFM sequence of the metatorbernite (001) surface in contact with water (a), and after injecting a basic aqueous solution ( $\mathrm{pH}=11.5$ ) $(b-d)$. Shallow etch pits appears immediately after injecting the basic solution. A comparison of the images demonstrates the dissolution process by rapid coalescence of pits (white arrows in b) and retreat of $\langle 100\rangle$ steps (black arrows). Time elapsed between successive images is around $4 \mathrm{~min}$.

two-step process: stoichiometric dissolution of the mineral surfaces and subsequent precipitation of a secondary phase from a supersaturated fluid in contact with the mineral surface. When a metastable crystalline solid is in contact with an aqueous solution, the solvent can actively take part in a phase transformation process by allowing the simultaneous dissolu-tion of the metastable phase and the crystallization of the stable phase. This solvent-mediated transformation mechanism involves a transformation where the phase transition occurs by breaking and formation of chemical bonds. Recent studies 35 have shown that altered (and porous) surfaces in silicate minerals interacted with acidic solutions can be explained by such a mechanism. The result of both processes (ion exchange and dissolution -precipitation) in our system would be the formation of a thermodynamically more stable solid than the pure-end member metatorbernite, probably with an inter-

mediate composition of $\left(\mathrm{Cu}_{1} / 2, \mathrm{H}_{3} \mathrm{O}\right)\left(\mathrm{UO}_{2}\right)_{2}\left(\mathrm{PO}_{4}\right) 2 \mathrm{H}_{2} \mathrm{O}$ and the formation of porosity and/or an altered layer as side effects. Both mechanisms are plausible because both would allow the system to reduce its free energy. 36,37 The analyzed concen-tration of the effluents yielded a concentration of $0.081 \pm 0.02$ and $0.013 \pm 0.005 \mu \mathrm{g} / \mathrm{mL}$ for $U$ and $\mathrm{Cu}$, respectively. These values are not far from the stoichiometry of metatorbernite and are in good agreement with those obtained by llton et al. 16 during the dissolution of metatorbernite at $\mathrm{pH}^{2} .5$ using nitric acid. If ion exchange were the mechanism controlling the transformation, an excess of $\mathrm{Cu}_{\mathrm{aq}}$ in the aqueous solution would be expected. Similarly, if the operating mechanism were stoichiometric dissolution followed by precipitation of a Cu-poorer new phase, an excess of $\mathrm{Cu}$ should also be detected in the fluid. Our analytic results do not support any of these mechanisms because they do not show an excess of $\mathrm{Cu}$ relative to U. On the other hand, the physical features observed in the AFM sequence of metatorbernite dissolution are hardly explainable by a perfectly stoichiometric dissolution mechanism. If this were not the case, then the analytical results would picture the overall effect of the metatorbernite surface dissolution which progresses heterogeneously over several surface patches developing transient intermediate solid compositions that eventually dissolve and expose a new pristine surface underneath. Therefore, in spite the analytical results showing a stoichiometric $\mathrm{Cu}: \mathrm{U}$ ratio they cannot definitely rule out any of these options because of the different scales of surface observation (bulk vs local).

A possibility is that the occurrence of altered layers can be explained as a result of nonstoichiometric dissolution which leads to the development of chemically and structurally altered near-surface zones (leached layers) between the fluid-solid interface and the unaltered mineral. ${ }^{38}$ At low $\mathrm{pH}$, in addition to the interlayer ion exchange reaction $\left(2 \mathrm{H}_{3} \mathrm{O}^{+} \leftrightarrow\right.$ $\mathrm{Cu}^{2+}$ ), an exchange of uranium by protons (acid hydrolysis) within the autunite-type sheet could also occur. Leaching of uranium would, therefore, leave isolated phosphate tetrahedral, determining the formation of an altered layer. This process would be enhanced by the fact that the rate of sorption of $\mathrm{H}^{+}$to the surface under such $\mathrm{pH}$ conditions sorption of (the pHpzc for sodium meta-autunite synthetic colloids ranges from 3 to 9 , 39 although a narrower range crystals). ${ }^{15}$ Again, both our analysis and those reported by llton
process wo not support this mechanism since such $\mathcal{V}_{\text {aq }}$ eaching respect to $\mathrm{Cu}_{\text {aq }}$. 
An alternative mechanism can operate on the metatorbernite (001) surface interacted with acidic solutions. If we assume a point defect covered surface where protons attack more easily, this process could induce the differential release of uranyl and phosphate structural units from the upper layer, punctuating the layer with several pits, creating this porous layer character, different from the step retreat observed at high $\mathrm{pH}$, and to be shown later. Such a mechanism can cause a physically altered layer, but it does not necessarily involve a nonstoichiometric dissolution and formation of a chemically altered layer. In any case, the combination of dissolution and surface structural heterogeneities (defects) in the metatorbernite structure are the likely explaination for both the collapse process and the alteration of the surfaces observed under acidic conditions. However, because of what has been previously discussed the actual nature of this transformation remains a matter of speculation.

3.3. Dissolution under $\mathrm{pH} \mathbf{1 1 . 5}$ Solution. The dissolution pattern of metatorbernite (001) surface in alkaline conditions can be easily ascribed to a "classical" dissolution model, i.e., generation and widening of shallow etch pits on the flat terraces. Figure 7 shows an AFM sequence of a metatorbernite (001) surface obtained after injecting a basic aqueous solution $(\mathrm{pH}=11.5)$. The surface rapidly begins to dissolve, mainly by the rapid widening of shallow etch pits generating on the flat terraces. During the initial stages of the dissolution, the microtopography of the surfaces is characterized by a high variability in the density of pits, which do not appear uniformly distributed on the surface. Whereas in certain areas (white arrows), the concentration of pits is extremely high, other areas remain relatively unaltered. The profusion of pits may be related to point defects, evidencing the high defectiveness of the surface. Pits exhibit different widening behavior depending on the areas where they form. The sequence from Figure $7 \mathrm{~b}$ to $\mathrm{d}$ shows that in areas with a high density of pits, they are short-lived since they immediately coalesce. In such areas dissolution occurs by a rapid dismantling of the surface. As a result, small patches of the former surface, bounded by rough steps, appear scattered on the dissolving surfaces (Figure $7 \mathrm{~b}$ ). In contrast to this behavior, the widening of pits in areas with low pit-density is mainly controlled by the retreat of elementary $\langle 100\rangle$ steps (see black arrows in Figure $7 b-d)$. The shape and orientation of these etch pits are parallel to the most straight PBCs and are consistent with the existence of a 4-fold axis perpendicular to the metatorbernite (001) face. The retreating speed for $\langle 100\rangle$ steps is around $0.15 \mathrm{~nm} / \mathrm{s}$. Since such steps are crystallographically equivalent, their retreating velocity is isotropic. Due to the high density of etch pits, the dissolution of the surface monolayers represents a rapid, but non-homogeneous phenomenon. The whole process of metatorbernite crystals dissolution seems to be controlled by the contribution of the cleavage (001) surface, the rougher $\{h 0 l\}$ surfaces, and especially the crystal edges and corners. The higher reactivity of metatorbernite $\{001\}$ surfaces interacted with alkaline solutions (in comparison with those interacted with circum-neutral solutions) is most probably explained by the formation of stable uranyl complexes with $\mathrm{CO}_{3}{ }^{2-}$ in solution. Under the alkaline conditions of our experiments $(\mathrm{pH}$ $=11.5$ ), the dissolved atmospheric carbon dioxide is mostly dissociated into the carbonate ion $\left(\left[\mathrm{CO}_{3}{ }^{2-}\right] \gg\left[\mathrm{HCO}_{3}{ }^{-}\right] \approx\right.$ $\left.\left[\mathrm{NaCO}_{3}{ }^{-}\right]\right)$. This ion rapidly reacts with the dissolved uranyl, forming very stable uranyl carbonate complexes such as $\mathrm{UO}_{2}\left(\mathrm{CO}_{3}\right)_{2}{ }^{2-}$ and, mainly $\mathrm{UO}_{2}\left(\mathrm{CO}_{3}\right)_{3}{ }^{4-}, 3,40$ enhancing
U(VI) solubility. Indeed, such complexes are probably the most important solution complexes responsible for $U$ migration in oxidizing environments. ${ }^{2,41}$ The fast retreating velocity of $\langle 100\rangle$ steps measured at high $\mathrm{pH}$ is in good agreement with macroscopic measurements of the dissolution of autunite minerals and metatorbernite conducted over the $\mathrm{pH}$ interval of $6-7$ to $10 .^{42,43}$ Such experiments revealed that the rate of autunite and metatorbernite dissolution increases as a function of increasing $\mathrm{pH}$ by a factor of $\sim 100 \times$.

\section{ENVIRONMENTAL IMPLICATIONS}

The environmental mobility of uranium, following the oxidative dissolution of primary mineralizations, is mostly controlled by the relative thermodynamic stability and dissolution kinetics of secondary uranyl-bearing phases, among which hydrated uranyl phosphates assume an unquestionable relevance. Understanding the dissolution mechanisms of these materials at different scales is crucial for both interpreting field data and predicting surface reactivity of secondary uranyl deposits in different aqueous settings. The present study, for the first time, probes surface dissolutive nanotopographic features, enabling a better understanding of what mechanisms may influence the reactive behavior of uranyl phosphates. From the outlined important results we should stress, as an eyestriking factor controlling reactivity and thus of environmental importance, the relationship between impurity incorporation, even at small amounts, and mechanisms of dissolution. It is our conviction that the pioneer research here presented should pave the way for a series of AFM studies with higher complexity, concerning important aspects of uranyl phosphate phase dissolution behavior (i.e., the effect of different background electrolytes, concurrent ions, thermal dissolution, etc.).

\section{AUTHOR INFORMATION}

\section{Corresponding Author}

*Tel.: +34913944881; e-mail: jmastill@ucm.es.

\section{Notes}

The authors declare no competing financial

\section{interest.}

\section{ACKNOWLEDGMENTS}

This work was partially supported by the Spain/Portugal Joint Research Programme (Acción Integrada AIB2010PT-00282) and the Ministerio de Ciencia e Innovación, Spain (Project CGL2010-20134-C02-01). A.J.P. acknowledges the support obtained from the postdoctoral scholarship funded by the FCT ("Fundação para a Ciência e Tecnologia", reference SFRH/ $\mathrm{BPD} / 65314 / 2009)$. We sincerely thank the Microscopy Centre, the X-ray Diffraction Central Service, and the Laboratory of Geochemistry and Environmental Analysis of the Complutense University (UCM) for kindly providing us access to the AFM and for technical assistance. We appreciate the insightful comments by three anonymous reviewers.

\section{REFERENCES}

(1) Merritts, D.; De Wet, A.; Menkig, K. Environmental Geology: An Earth System Science Approach; W.H. Freeman and Company: New York, 1998.

(2) Finch, R.; Murakami, T. Systematics and paragenesis of Uranium Minerals. In Uranium: Mineralogy, Geochemistry and the Environment; Burns, P. C., Finch, R., Eds.; Reviews in Mineralogy 38; The Mineralogical Society of America: Washington, DC, 1999; pp 91. 
(3) Abdelouas, A. Uranium mill tailings: Geochemistry, mineralogy, and environmental impact. Elements 2006, 2 (6), 335-341, DOI: 10.2113 /gselements.2.6.335.

(4) Abdelouas, A.; Lutze, W.; Nuttall, H. E. Uranium Contamination in the subsurface: Characterization and Remediation. In Uranium: Mineralogy, Geochemistry and the Environment; Burns, P. C., Finch, R., Eds.; Reviews in Mineralogy 38; The Mineralogical Society of America: Washington, DC, 1999; pp 433.

(5) Fuller, C. C.; Bargar, J. R.; Davis, J. A.; Piana, M. J. Mechanisms of uranium interactions with hydroxyapatite: Implications for groundwater remediation. Environ. Sci. Technol. 2002, 36 (2), 158-165, DOI: $10.1021 /$ es0108483.

(6) Arey, J. S.; Seaman, J. C.; Bertsch, P. M. Immobilization of uranium in contaminated sediments by hydroxyapatite addition. Environ. Sci. Technol. 1999, 33 (2), 337-342, DOI: 10.1021/ es980425+.

(7) Ohnuki, T.; Kozai, N.; Samadfam, M.; Yasuda, R.; Yamamoto, S.; Narumi, K.; Naramoto, H.; Murakami, T. The formation of autunite $\left(\mathrm{Ca}\left(\mathrm{UO}_{2}\right)\left(\mathrm{PO}_{4}\right) 2 \cdot \mathrm{nH}_{2} \mathrm{O}\right)$ within the leached layer of dissolving apatite: incorporation mechanism of uranium by apatite. Chem. Geol. 2004, 211 (1-2), 1-14, DOI: 10.1016/j.chemgeo.2004.03.004.

(8) Jerden, J. L., Jr.; Sinha, A. K.; Zelazny, L. Natural immobilization of uranium by phosphate mineralization in an oxidizing saprolite-soil profile: Chemical weathering of the Coles Hill uranium deposit, Virginia. Chem. Geol. 2003, 199 (1-2), 129-157, DOI: 10.1016/ S0009-2541(03)00080-9.

(9) Catalano, J. G.; McKinley, J. P.; Zachara, J. M.; Heald, S. M.; Smith, S. C.; Brown, G. E. Changes in uranium speciation through a depth sequence of contaminated Hanford sediments. Environ. Sci. Technol. 2006, 40 (8), 2517-2524, DOI: 10.1021/es0520969.

(10) Arai, Y.; Marcus, M. A.; Tamura, N.; Davis, J. A.; Zachara, J. M. Spectroscopic evidence for uranium precipitates in vadose zone sediments at the Hanford 300-Area site. Environ. Sci. Technol. 2007, 41 (13), 4633-4639, DOI: 10.1021/es062196u.

(11) Singer, D. M.; Zachara, J. M.; Brown, G. E. Uranium Speciation as a function of depth in contaminated Hanford sediments - A MicroXRF, Micro-XRD, and Micro- and bulk-XAFS study. Environ. Sci. Technol. 2009, 43 (3), 630-636, DOI: 10.1021/es8021045.

(12) Stubbs, J.; Veblen, L.; Elbert, D.; Zachara, J.; Davis, J.; Veblen, D. Newly recognized hosts for uranium in the Hanford Site vadose zone. Geochim. Cosmochim. Acta 2009, 73 (6), 1563-1576, DOI: 10.1016/j.gca.2008.12.004.

(13) Isobe, H.; Murakami, T.; Ewing, R. C. Alteration of uranium minerals in the Koongarra deposit, Australia: Unweathered zone. J. Nucl. Mater. 1992, 190, 174-187, DOI: 10.1016/0022-3115(92) 90085-Y.

(14) Pinto, A. J.; Gonçalves, M. A.; Prazeres, C.; Astilleros, J. M.; Batista, M. J. Mineral replacement reactions in naturally occurring hydrated uranyl phosphates from the Tarabau deposit: Examples in the $\mathrm{Cu}-\mathrm{Ba}$ uranyl phosphate system. Chem. Geol. 2012, 312-313, 18-26, DOI: $10.1016 /$ j.chemgeo.2012.04.004.

(15) Wellman, D. M.; Gunderson, K. M.; Icenhower, J. P.; Forrester, S. W. Dissolution kinetics of synthetic and natural meta-autunite minerals, $\mathrm{X}_{3-\mathrm{n}}^{(\mathrm{n})+}\left[(\mathrm{UO})_{2}\left(\mathrm{PO}_{4}\right)\right]_{2} \cdot \mathrm{xH}_{2} \mathrm{O}$, under acidic conditions. Geochem. Geophys. Geosyst. 2007, 8, Q110001 DOI: 10.1029/ 2007GC001695.

(16) Ilton, E. S.; Zachara, J. M.; Moore, D. A.; McKinley, J. P.; Eckberg, A. D.; Cahill, C. L.; Felmy, A. R. Dissolution study of metatorbernite: thermodynamic properties and the effect of $\mathrm{pH}$ and phosphate. Environ. Sci. Technol. 2010, 44 (19), 7521-7526, DOI: $10.1021 /$ es101619f.

(17) Smeaton, C. M.; Weisener, C. G.; Burns, P. C.; Fryer, B. J.; Fowle, D. A. Bacterially enhanced dissolution of meta-autunite. Am. Mineral. 2008, 93 (11-12), 1858-1864, DOI: 10.2138/am.2008.2836. (18) Schindler, M.; Hawthorne, F. C.; Putnis, C.; Putnis, A. Growth of uranyl-hydroxy-hydrate and uranyn carbonate minerals on the (104) surface of calcite. Can. Mineral. 2004, 42 (6), 1683-1697, DOI: 10.2113 /gscanmin.42.6.1683.
(19) Schindler, M.; Putnis, A. Crystal growth of schoepite on the (104) surface of calcite. Can. Mineral. 2004, 42 (6), 1667-1681, DOI: 10.2113 /gscanmin.42.6.1667.

(20) Schindler, M.; Hawthorne, F. C.; Mandaliev, P.; Burns, P. C.; Maurice, P. A. An integrated study of uranyl mineral dissolution processes: Etch pit formation, effects of cations in solution, and secondary precipitation. Radiochim. Acta 2011, 99 (2), 79-94, DOI: $10.1524 /$ ract.2011.1802.

(21) Locock, A. J.; Burns, P. C. Crystal structures and synthesis of the copper-dominant members of the autunite and meta-autunite groups: Torbernite, zeunerite, metatorbernite and metazeunerite. Can. Mineral. 2003, 41 (2), 489-502, DOI: 10.2113/gscanmin.41.2.489.

(22) Burns, P. C. The crystal chemistry of uranium. In Uranium: Mineralogy, Geochemistry and the Environment; Burns, P. C., Finch, R. Eds.; Reviews in Mineralogy 38; The Mineralogical Society of America: Washington, DC, 1999; pp 23.

(23) Stergiou, A. C.; Rentzeperis, P. J.; Sklavounos, S. Refinement of the crystal structure of metatorbernite. Z. Kristallogr. 1993, 205, 1-7, DOI: 10.1524/zkri.1993.205.Part-1.1(1993).

(24) Brown, I. D. Bond valence parameters (bvparm2011.cif); 2011. http://www.iucr.org/resources/data/datasets/bond-valenceparameters.

(25) Kostov, I.; Kostov, R. I. Crystal Habits of Minerals; Bulgarian Academic Monographs (1); Pensoft Publishers: Sofia, 1999.

(26) Putnis, A. Introduction to Mineral Sciences; Cambridge University Press: Cambridge, 1992.

(27) Vochten, R.; Piret, P.; Goeminne, A. Synthesis, crystallographic data, solubility and electrokinetic properties of copper-uranylphosphate, nickel-uranylphosphate and cobalt-uranylphosphate. Bull. Mineral. 1981, 104, 457-467.

(28) Magalhães, M. C. F.; Pedrosa de Jesus, J. D.; Williams, P. A. The chemistry of uranium dispersion in groundwaters at the PinhaldoSouto mine, Portugal. Inorg. Chim. Acta 1985, 109 (2), 71-78, DOI: $10.1016 /$ S0020-1693(00)84544-2.

(29) Gorman-Lewis, D.; Burns, P. C.; Fein, J. B. Review of uranyl mineral solubility measurements. J. Chem. Thermodyn. 2008, 40, 335352, DOI: $10.1016 /$ j.jct.2007.12.004.

(30) Jordan, G.; Higgins, S. R.; Eggleston, C. M.; Swapp, S. M.; Janney, D. E.; Knauss, K. G. Acidic dissolution of plagioclase: In-situ observations by hydrothermal atomic force microscopy. Geochim. Cosmochim. Acta 1999, 63 (19/20), 3183-3191, DOI: 10.1016/ S0016-7037(99)00225-2.

(31) Ross, V. Studies of uranium minerals (XXI): Synthetic hydrogen-autunite. Am. Mineral. 1955, 40 (9/10), 917-919.

(32) Putnis, A. Mineral replacement reactions: From macroscopic observations to microscopic mechanisms. Mineral. Mag. 2002, 66 (5), 689-708, DOI: 10.1180/0026461026650056.

(33) Putnis, A. Mineral replacement reactions. In Thermodynamics and Kinetics of Water-Rock Interaction; Oelkers, E. H., Schott, J., Eds.; Reviews in Mineralogy and Geochemistry 70; The Mineralogical Society of America, Washington, DC, 2009; p 87. DOI 10.2138/ rmg.2009.70.3.

(34) Putnis, A.; Putnis, C. V. The mechanism of reequilibration of solids in the presence of a fluid phase. J. Solid State Chem. 2007, 180 (5), 1783-1786, DOI: org/10.1016/j.jssc.2007.03.023.

(35) Ruiz-Agudo, E.; Putnis, C. V.; Rodriguez-Navarro, C.; Putnis, A. The mechanism of leached layer formation during chemical weathering of silicate minerals. Geology 2012, 40 (10), 947-950, DOI: $10.1130 / \mathrm{G} 33339.1$.

(36) Astilleros, J. M.; Pina, C. M.; Fernández-Díaz, L.; Putnis, A. Supersaturation functions in binary solid solution-aqueous solution systems. Geochim. Cosmochim. Acta 2003, 67 (9), 1601-1608, DOI: $10.1016 /$ S0016-7037(02)01166-3.

(37) Prieto, M.; Astilleros, J. M.; Pina, C. M.; Fernández-Díaz, L.; Putnis, A. Coment: Supersaturation in binary solid solution - aqueous solution systems. Am. J. Sci. 2007, 307, 1034-1045, DOI: 10.2475/ 07.2007.04

(38) Casey, W. H.; Westrich, H. R.; Massis, T.; Banfield, J. F.; Arnold, G. W. The surface of labradorite feldspar after acid hydrolysis. 
Chem. Geol. 1989, 78 (3/4), 205-218, DOI: 10.1016/0009-2541(89) 90058-2.

(39) Zheng, Z.; Wan, J.; Song, X.; Tokunaga, T. K. Sodium metaautunite colloids: Synthesis, characterization, and stability. Colloids Surf., A 2006, 274, 48-55, DOI: 10.1016/j.colsurfa.2005.08.032.

(40) Reeder, R. J.; Nugent, M.; Drew Tait, C.; Morris, D. E.; Heald, S. M.; Beck, K. M.; Hess, W. P.; Lanzirotti, A. Coprecipitation of Uranium(VI) with Calcite: XAFS, micro-XAS, and luminescence characterization. Geochim. Cosmochim. Acta 2001, 65 (20), 34913503, DOI: 10.1016/S0016-7037(01)00647-0.

(41) Clark, D. L.; Hobart, D. E.; Neu, M. P. Actinide carbonate complexes and their importance in actinide environmental chemistry. Chem. Rev. 1995, 95 (1), 25-48, DOI: 10.1021/cr00033a002.

(42) Wellman, D. M.; Icenhower, J. P.; Gamerdinger, A. P.; Forrester, S. W. Effects of $\mathrm{pH}$, temperature, and aqueous organic material on the dissolution kinetics of meta-autunite minerals, $(\mathrm{Na}, \mathrm{Ca})_{2-1}\left[\left(\mathrm{UO}_{2}\right)\right.$ $\left.\left(\mathrm{PO}_{4}\right)\right]_{2} \cdot 3 \mathrm{H}_{2} \mathrm{O}$. Am. Mineral. 2006, 91 (1), 143-158, DOI: 10.2138/ am.2006.1807.

(43) Wellman, D. M.; McNamara, B. K.; Bacon, D. H.; Cordova, E. A.; Ermi, R. M.; Top, L. M. Dissolution Kinetics of meta-torbernite under circum-neutral to alkaline conditions. Environ. Chem. 2009, 6 (6), 551-560, DOI: 10.1071/EN09046. 